AGRARIS: Journal of Agribusiness and Rural Development Research

Vol. 7 No. 2 July - December 2021 Pages: 241-255

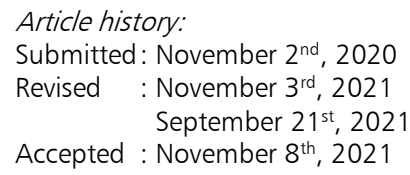

Agustina Shinta Hartati Wahyuningtyas, Novi Haryati*, Destyana Ellingga Pratiwi, and Luisa Maliny Situmeang

Department of Agricultural Socio-Economics, Faculty of Agriculture, Universitas Brawijaya, Jl. Veteran Kota Malang 65145, Indonesia

*) Correspondence email: noviharyati@ub.ac.id

\title{
Risk Mitigation Strategies in Semi-Organic Rice Supply Chains: Lesson Learned from the Involved Actors
}

\author{
DOI: https://doi.org/10.18196/agraris.v7i2.10126
}

\begin{abstract}
Rice is the main consumption food for Indonesians. The demand for food increased from $114.6 \mathrm{~kg}$ per capita in 2016 to $124.89 \mathrm{~kg}$ in 2017 . However, rice farmers and supply chain actors in rice agribusiness have experienced high challenges, such as production, transportation, price, product quality, and the environment. This research aimed to understand actors involved in the supply chain, their perception of occurring risks, and evaluation and risk mitigation in the supply chain. This was a quantitative descriptive study done purposively in Watugede Village, Singosari Sub-District, Malang Regency. Non-probability sampling was taken to gather primary data. The respondent of this research was 16 involved actors, from on-farm actors to consumers. The data were analyzed using the Fuzzy analytical hierarchy process (FAHP) to provide descriptive risk mitigation strategies. The results show that six involved actors are suppliers, farmers, grinders, traders, and buyers. Each actor faces different risks, and thus, the recommended mitigation strategies are adjusted to their risks. Sharing information, optimizing the level of supply availability, measuring supply chain performance, and building more coordination with the government are the best strategies to mitigate risks.
\end{abstract}

Keywords: Mitigation, rice, risk, supply chains

\section{INTRODUCTION}

Gross domestic product (GDP) from the agricultural sector in Indonesia increased to $73.3 \%$ in the first quarter of 2019 from IDR 46,173.20 billion in the fourth quarter of 2018; the increase reaches an average of IDR 68,735.56 billion from 2010 to 2019 (Food and Agriculture Organization [FAO], 2021). Therefore, certain agricultural products with high selfsufficiency received special attention in the blueprint of the ASEAN Economic Community (AEC). In particular, this condition applies to rice which by far is one of the four strategic commodities. Typical risks occur in every supply chain management, including interruptions and delays caused by suppliers, such as supply capacity (Bollapragada et al., 2004; Cachon \& Lariviere, 1999; Ellram, 1990; Feng, 2010; Kahraman et al., 2003; Wu et al., 2008), product design changes (Novak \& Eppinger, 2001) and delivery delays (Feng, 2010). 
Meanwhile, other risks are due to exchange rates, inventory, and out of stock (Halldórsson et al., 2009), logistics, and transportation risks (Santis et al., 2017). The demand risks include demand volatility and forecasting inaccuracies, information distortion, and stock accumulation due to bullwhip effects (Kahraman et al., 2003).

Other researchers divide the risks into environmental, social, and financial risks. Environmental risk is a consequence of natural ecosystems, corporate reputation, financial compliance, and legal compliance (Cachon \& Lariviere, 1999). Meanwhile, social risk refers to sending responsibility to employees, consumers, business partners, the government, and society. Other examples of social risks include business scandals that employ underage workers, unethical treatment of animals, illegal environmental practices, pricing, allegations of bribery, fraud, and patent infringement (Hammoudi et al., 2009). The financial dimension separates financial risks performed by financial environment, corporate, and individual behavior and strives for continuous economic growth (Blome \& Schoenherr, 2011).

Sustainability is generally related to risks encountered by industries, such as greenhouse gas emissions, natural disasters, accidents, energy consumption, waste, and environmental damage during shipping and transportation. The sustainability risks include resistance to boycotting a company's products, litigation against companies to cover financial losses caused by environmental accidents, non-compliance with regulations, or unethical behavior, risks of social justice from unfair workers and work practices, and increasing commodity and energy prices as fuel shortages (Spekman \& Davis, 2004).

Economic risks are related to uncertainty in a country's economic conditions, interest rates, business trends like increasing outsourcing or offsourcing and information technology used to develop sustainable supply chains (Zhou \& Benton, 2007). The impact of these risks is the increasing costs, and thus, a strategy for resource allocation and capacity development to manage risks is necessary (Tang \& Nurmaya Musa, 2011). One technique to manage risk is to provide incentives in the supply chain, and thus suppliers can work together following the contract and provide reliable guarantees (Matzembacher \& Meira, 2019). After analyzing the risks of the supply chain, this study was expected to find a strategy to prevent or eliminate risks for the rice supply chain. Rice farmers in Watugede Village Singosari have experienced high challenges in their supply chains since they produce semi-organic rice with different marketing processes. Besides, other challenges are production, transportation, price, product quality, and the environment. Therefore, this research was conducted to understand 1) actors involved in the supply chain, 2) their perception of occurring risks, and 3) evaluation and risk mitigation in the supply chain. This research is expected to provide theoretical contributions for the actor mapping and supply chain risk mitigation, as well as practical contributions for advice and inputs for supply chain actors.

\section{RESEARCH METHOD}

This research employed a quantitative descriptive approach Queirós, Faria, \& Almeida, (2017) because this research involved data in numbers. The data were obtained from interviews conducted in each supply chain. The descriptive method was also used to describe 
each actor in a semi-organic rice supply chain. This method identified sources of risks perceived by each actor in the semi-organic rice supply chain. Identifying risks perceived by each supply chain actor can be seen from the respondents' answers on the questionnaire using the Likert scales. The scales were $1-5$ with the following descriptions: $1=$ very unimportant, 2 $=$ not important, 3 = doubtful, 4 = important, and 5 = very important.

Furthermore, this study employed the judgment sampling technique to answer the objective of supply chain risk. This technique considers the determined characteristics of target populations and is adapted to the research purposes or problems Queirós, Faria, \& Almeida, (2017). This research employed the primary data collected with the structured questionnaires based on the research purposes. The research site was Watugede village, Singosari Sub-district, Malang Regency, Indonesia. The data were analyzed using the fuzzy AHP. The research respondents are the actors of each supply chain. They were one supplier, three farmers, three loggers, three grinders, three traders, and three consumers. The research framework was summarized in Figure 1.

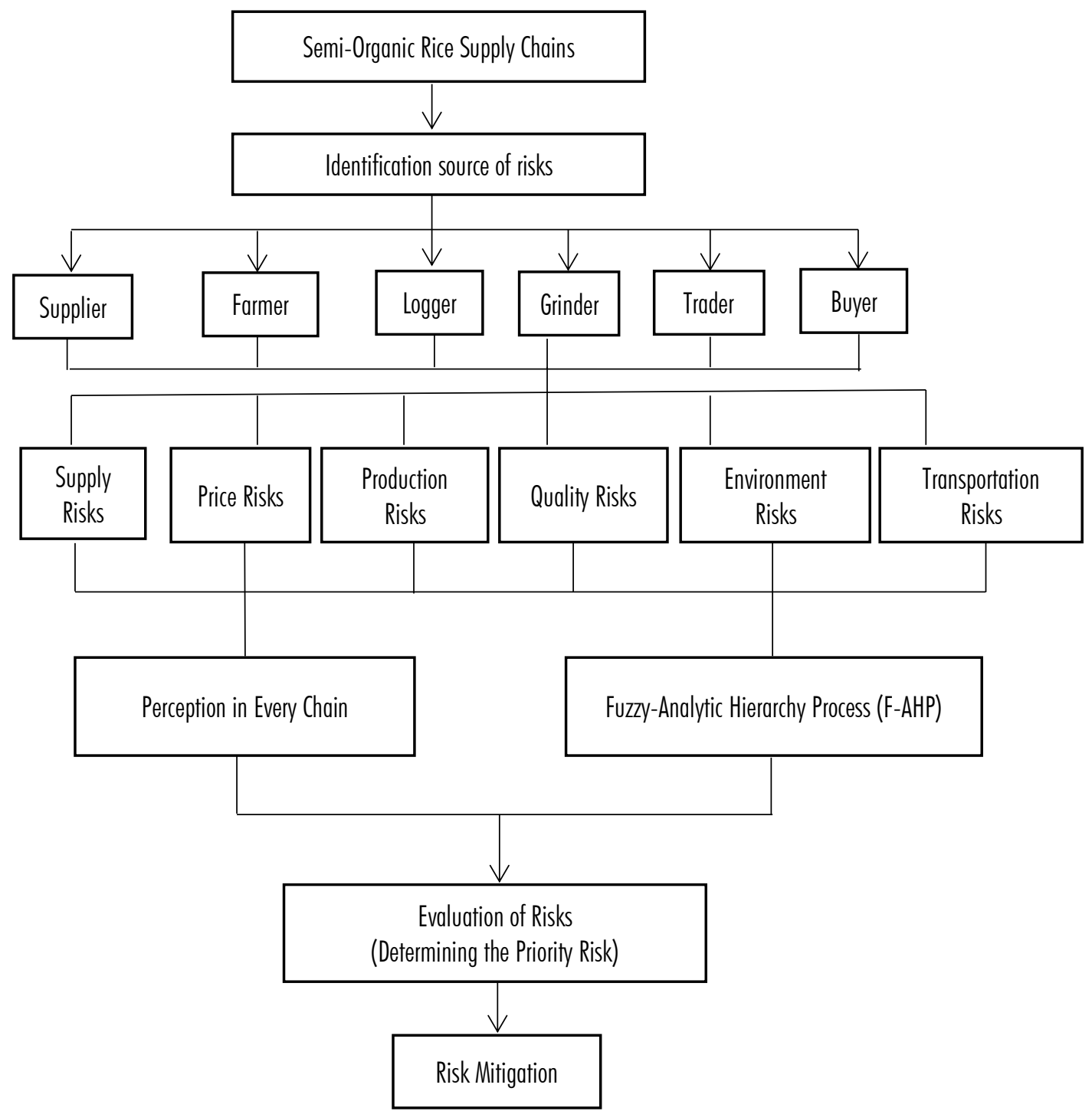

FIGURE 1. THE RESEARCH FRAMEWORK OF SEMI-ORGANIC RICE SUPPLY CHAINS MITIGATION 
Fuzzy AHP (analytical hierarchy process) is the best method to determine the weight of each risk factor (Feng, 2010). Meanwhile, the risk factors were selected using the highest weight with expert judgment inputs. In general, this study developed the fuzzy AHP method through eight stages.

1. The first stage was identifying risk problems. The criteria of risk selection were supply, transportation, price, quality, and environment.

2. The second stage was creating a hierarchical structure to represent a complex problem in the risk selection. The sub-criteria of risk selection were diversity of supply, uncertain supply, damaged infrastructures, uncertain time, transportation, road insecurity, long haul distances, inflation, price fluctuations, information distortion, low quality, quality variations, government policy, political, social, and cultural conditions, and competitors' products.

3. The third stage was choosing alternative assessments and criteria. This stage is pivotal to determine the priority criteria from every tier of semi-organic rice, including suppliers, farmers, loggers, grinders, traders, and buyers.

4. The fourth stage was fuzzy fiction from the results of assessing and performing defuzzification of the fuzzy score. This stage was done by making criteria and alternative matrices.

5. The fifth stage was calculating the eigenvector values and testing their consistency. If the values are not consistent, the data collection should be repeated. The eigenvector values in questions refer to the maximum obtained eigenvector value.

6. The sixth stage was calculating ratio consistency and final scores, determining the ranking of the final scores (Santis et al., 2017), and testing the hierarchy consistency. If the scores do not meet the CR $<0.100$, the assessment must be repeated.

7. The seventh stage was evaluating the highest priority of the most important risks in the criteria and sub-criteria.

The last stage was determining the risk mitigation strategies for each actor in the semiorganic rice supply chain. The mitigation strategies were determined by conducting a discussion between the researchers and respondents, actors in the semi-organic rice supply chain.

\section{RESULT AND DISCUSSIONS}

\section{Semi-Organic Rice Supply Chains}

The post-harvest rice supply chain in Singosari District involves several actors. The rice supply chain flow consists of the rice supply chain flow, such as supply chains for grain, rice bran, and husk. Each supply chain flow had product, financial, and information flows. However, this research limited its investigation to the post-harvest supply chains. Actors involved in the post-harvest supply chain were farmers, grain traders, mills, rice traders, retailers of markets, stalls, and shops, brick entrepreneurs, and breeders. These actors were mentioned in Figure 1. 


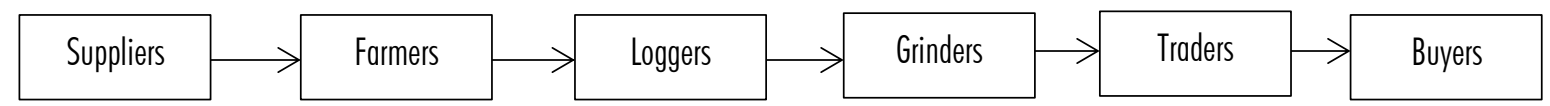

FIGURE 2. THE SEMI-ORGANIC RICE SUPPIY CHAIN

In the post-harvest, the semi-organic rice experienced changes in values from grain to rice readily consumed, and in the flow of post-harvest yield received by the grinders (wet rice). Wet rice was the main raw material in the rice milling process to become rice. Wet grains were initially dried in the sun to reduce the water content until they are ready for the grinding process. Dry milled grain was included in the rice milling system. Farmer groups have provided milling facilities for their members, although they are not required to deposit to farmer groups.

\section{Evaluating the Highest Risk Priority for Each Supply Chain actors of Semi-Organic Rice}

Risks at the Supplier Level

The result of weighting risk using the fuzzy AHP shows that the highest risk weighting at the supplier level was supply risk. The following high risks were quality risks, environmental risks, production risks, price risks, and transportation risks. The rating was considered valid because its $\mathrm{CR}$ value is 0.01 or $<0.1$. The risk of weighting results at the supplier level is presented in Figures 3 and 4. There were five criteria to examine the risks for actors of semiorganic rice supply chains. They were the supply, transportation, price, quality, and environment. Figure 3 shows that the highest risk priority was the supply risk by 0.301 . The successive risk priorities were the transportation risk by 0.078 , the price risk by 0.280 , the quality risk by 0.259 , and the environmental risk by 0.081 . The sub-criterion risks to supply risks are presented in Figure 4. The figure signifies that the uncertain supply has the highest risk of the supplier's activities by 0.81 , while the score of diversity in supply was 0.19 . Supply risks faced by the supplier refer to risks in the uncertain supply availability to meet farmers' needs. Goods that are only provided by suppliers were commodities highly needed by farmers. Meanwhile, suppliers wait for the total items requested by farmers to cultivate rice.

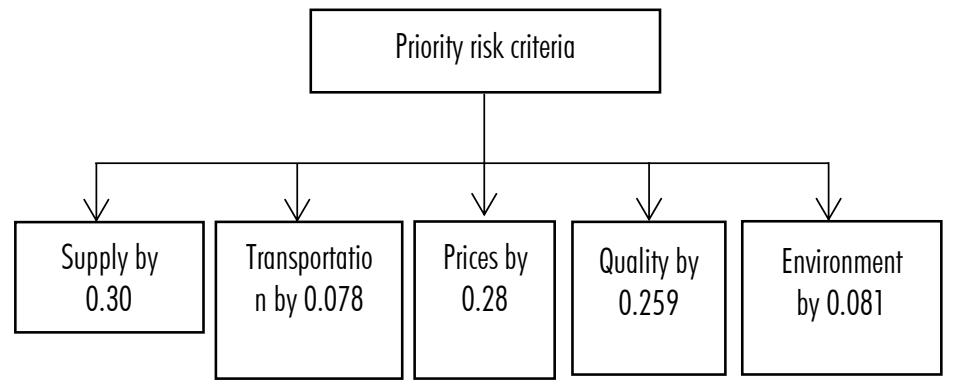

FIGURE 3. THE WEIGHTING STRUCTURE OF RISK PRIORITY CRITERIA AND SUBCRITERIA AT THE SUPPLIER LEVEL

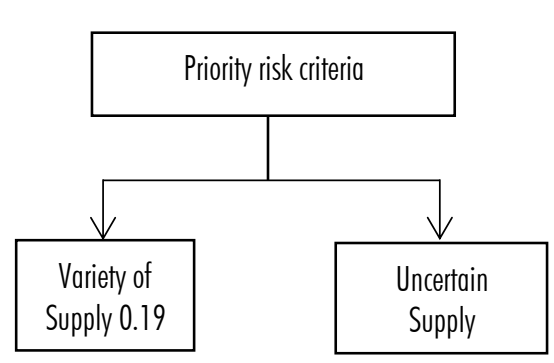

FIGURE 4. THE WEIGHTING STRUCTURE OF RISK PRIORITY AT THE SUPPLIER LEVEL

Therefore, the most troubling conditions for suppliers are when farmers do not need supplies or pay attention to the available supplies. However, when farmers need supplies, then the suppliers must immediately provide the available supply. If the supply is absent, the farmers are angry, sue the suppliers, or protest against them. 
Risks at the Farm Level

The farm level was analyzed to determine the risks faced by farmers in the supply chain management to improve the quality of semi-organic rice products. The result of weighting risk factors using the fuzzy AHP shows that the highest risk factor at the farm level was the environmental risk. Meanwhile, the following factors were quality, price, supply, production, and transportation risks. Rating was considered valid because its CR value was 0.04 or $<0.1$. The risk factor of weighing results at the farm level are presented in Figure 5. There were six criteria to examine the risks for actors of semi-organic rice supply chains. They were supply, transportation, price, quality, environment, and production.

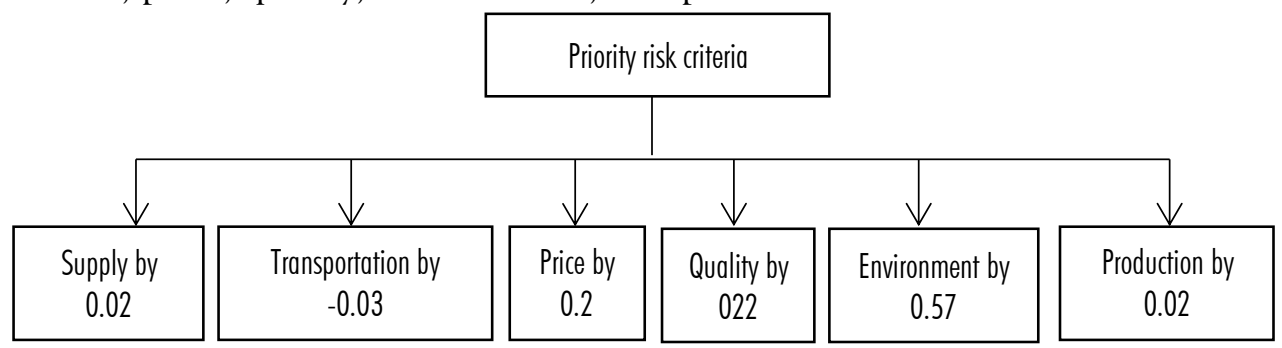

FIGURE 5. PRIORITY RISK CRITERIA AND SUB-CRITERIA AT THE FARMER LEVEL

Figure 5 demonstrates that the highest risk priority at the farmer level was the environmental risk by 0.507 . The transportation risk weights -0.03 , the supply risk weights 0.02 , the price risk weights 0.28 , the quality risk weights 0.22 , and the production risk weights 0.02. Meanwhile, the risk sub-criteria in the environmental risks are presented in Figure 6.

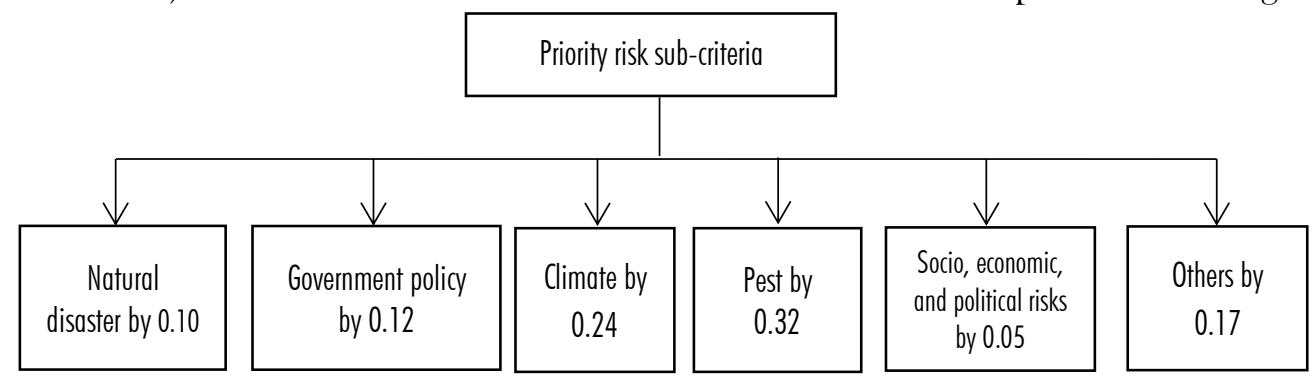

FIGURE 6. RISK PRIORITY AT THE FARMER LEVEL

Figure 6 denotes that the pests and diseases are at the highest risk for farmer activities with a weight of 0.32 . Other risks are the natural disaster risk with a weight of 0.10 , the government policy risk with a weight of 0.12 , the climate risk with a weight of 0.24 , the risk of political, social, and cultural conditions weight 0.05 , and the competitor's product risk weights 0.17 . The highest risk of pests or diseases to the farmers' activities refers to the number of pests, such as rats, that make farmers experience huge losses. Pests in agriculture are plantdisturbing organisms that damage the crops physically and physiologically. These pests cause crop failure, decrease the amount of crop production, disturb rice growth, decrease the economic value of production, and cause losses to farmers. Farmers and the community have done various ways to control rats, such as biological, sanitary, mechanical, and chemical methods, but they always fail and suffer from crop failure. Besides pests, diseases, such as bacterial leaf blight, often attack rice plants. This disease attacks rice leaves and is similar to stem borer attacks. Another disease is a leaf spot disease caused by fungus. 
Risks at the Logger Level

The analysis level was conducted to determine the risks compulsorily faced in the supply chain management to improve the quality of semi-organic rice products. The result of weighting risk factors using fuzzy AHP shows that the highest risk factor to the logger level was the environmental risk. The successive high factors were price, quality, supply, and transportation risks. The rating was considered valid because its CR value was 0.03 or $<0.1$. The weighting results of the risk factor at the log level are presented in Figure 7. This study employed five criteria to examine the risks to actors of semi-organic rice supply chains. They were supply, transportation, price, quality, and environment. The following structures are weighting priority risk criteria and risk sub-criteria at the logger level.

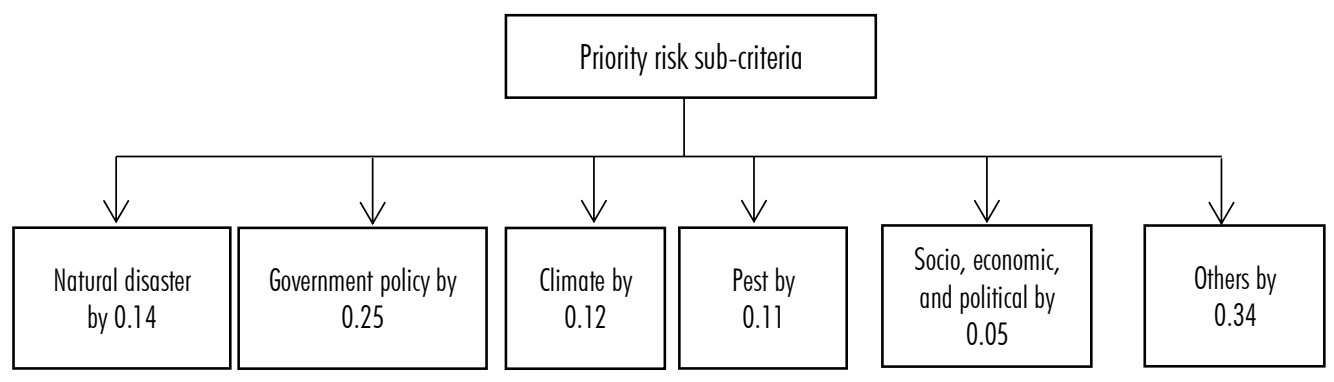

FIGURE 7. THE PRIORITY WEIGHTING STRUCTURE OF RISK CRITERIA AT THE LOGGING LEVEL

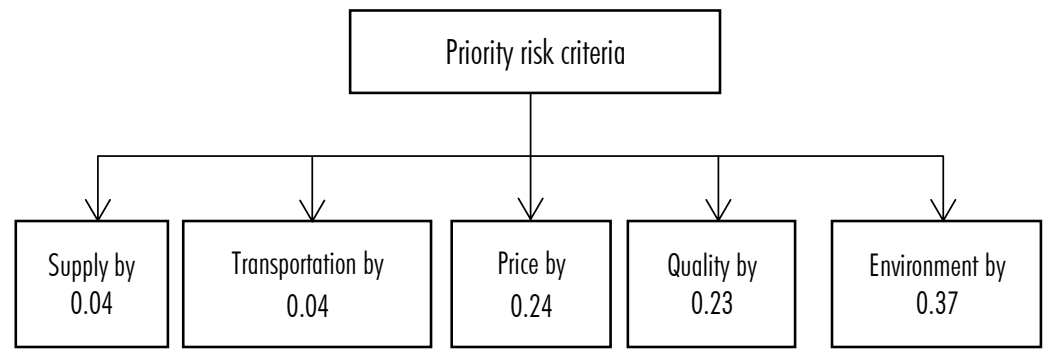

FIGURE 8. PRIORITY WEIGHTING STRUCTURE OF ENVIRONMENTAL RISK SUB-CRITERIA AT THE LOGGING LEVEL

Figure 7 shows that the highest risk priority at the logging level was the environmental risk by 0.37 . The supply risk weights are 0.04 , the transportation weights 0.04 , the price risk weights 0.24 , the quality risk weights 0.23 , and the environmental risk weights 0.37 . Figure 8 shows that the risk of competing products was the highest risk to logging activities with a weighting of 0.34 . Other risks were the natural disaster risk with a weight of 0.14 , the government policy risk with a weight of 0.25 , the climate risk with a weight of 0.12 , the risk of social, political, and cultural conditions with a weight of 0.05 , and pest or disease risk with a weight of 0.17 . The competitors' product risk in question refers to competition among loggers when cutting grains from farmers. In addition, when harvesting in other cities, many products from those cities were brought to Watugede Village. Consequently, the product prices from this village fall and loggers suffer from losses. In addition, the government policies also cause the risk because of insufficient relation to the rice entry distribution in Watugede Village.

Risks at the Grinder Level

Risk identification at the grinder level using the fuzzy AHP obtained the highest priority risk faced by grinders in the semi-organic rice supply chain was the price risk. The next high- 
priority risks were quality, production, supply, transportation, and environmental risks. The risk assessment was considered valid because its CR value was 0.06 or $<0.1$. Figure 9 shows the calculation results using Fuzzy. There were six criteria used to examine the risks to actors of semiorganic rice supply chains. They were the supply, transportation, price, quality, environment, and production. The following is the weighting structure of priority risk criteria and risk sub-criteria at the grinder level.

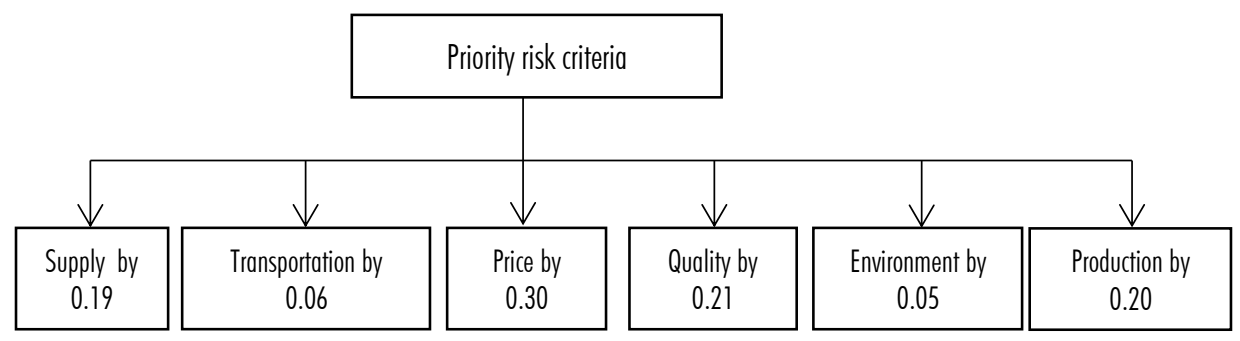

FIGURE 9. PRIORITY WEIGHTING STRUCTURE OF RISK CRITERIA AT THE GRINDER LEVEL

Figure 9 describes that the highest risk priority at the grinder level was the price risk by 0.30. The supply risk weights were 0.19 ; the transportation risk had a weight of 0.06 , the quality risk weights 0.21 , the environmental risk weights 0.05 , and the production risk weights 0.37. The risk sub-criteria on environmental risks are presented in Figure 10. The figure presents that the price fluctuation was the highest risk to grinder activities with a weight of 0.62 . Another risk is inflation with a weight of 0.23 . The risk of information distortion weights 0.15. Price fluctuations occur in two situations. When production is abundant, prices will greatly decrease. Conversely, when production is small, prices will rise. In addition, price fluctuations occur because the quality of rice was not good due to the damage when drying the grain, and there are a lot of rice stocks or broken rice due to uncertain weather conditions. The poor grain quality makes the grinder recognize that they should reduce the rice price for the retailers and consumers. In addition, the desire of retail traders and consumers to low prices causes grinders to suffer from loss. If direct sales are made to consumers, the grinder will receive a higher price because the direct sales can be directly adjusted to market prices. However, if a sale was made to a trader, the received price will be lower because the price was adjusted to the price at the grinder level.

\section{Risks at the Trader Level}

The risk identification at the trader level using the fuzzy AHP obtained risk priorities faced by traders in the semi-organic rice supply chain. The price and quality risks were the highest priorities. The next priorities were environmental risk, supply risk, and risk transportation. The assessments will produce priority weights investigating the value of each risk. The rating was considered valid because its $C R$ value was 0.04 or $<0.1$. Five criteria were employed to examine the risks to actors of semi-organic rice supply chains. They were supply, transportation, price, quality, and environment. The following structures are the weighting of priority risk criteria and risk sub-criteria at the retail trader level. 


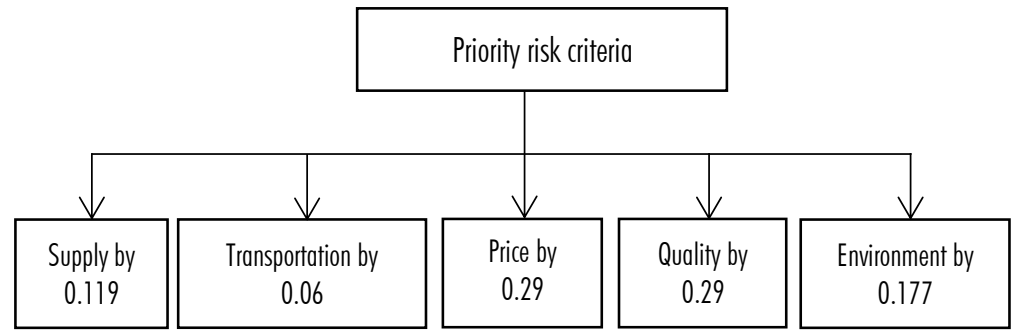

FIGURE 11. PRIORITY WEIGHTING STRUCTURE OF RISK CRITERIA AT THE RETAIL = TRADER LEVEL

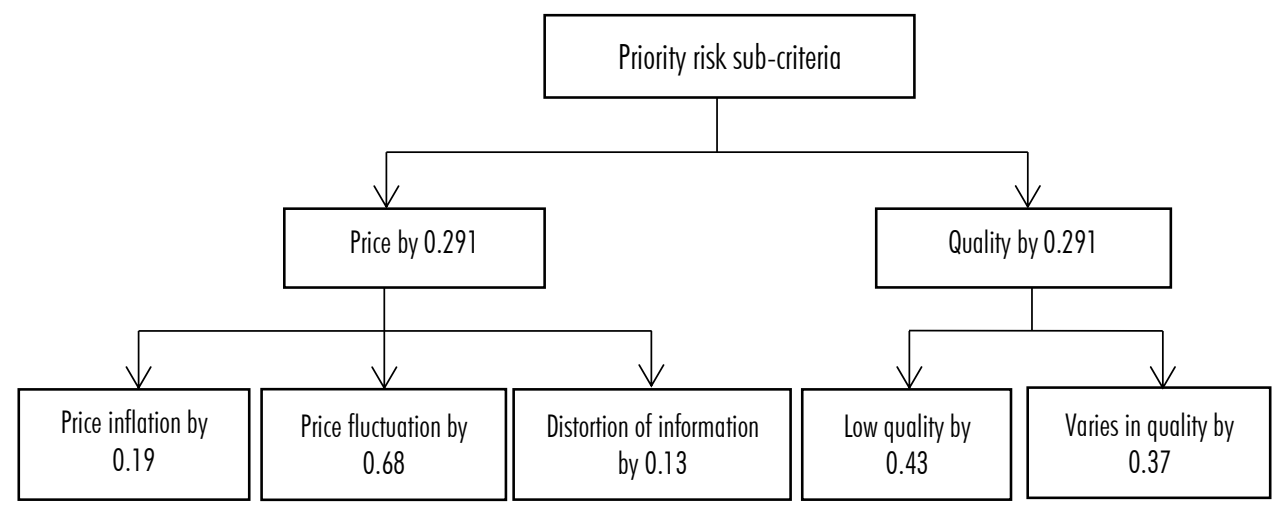

FIGURE 12. PRIORITY WEIGHTING STRUCTURE OF PRICE AND QUALITY RISK SUB-CRITERIA AT THE RETALL TRADER LEVEL

Figure 11 shows that the highest risk priority at the retail level was the price and quality risk by 0.291 . The supply risk weights 0.119 , the transportation risk weights 0.122 , and the environmental risk weights 0.177 . The risk sub-criteria of the price and quality risk are presented in Figure 12. The figure shows that the price fluctuation was the highest price risk to trader activities with a weight of 0.68 . Other risks were inflation with a weight of 0.19 and the information distortion risk with a weight of 0.13 . Quality variation also becomes the highest quality risk to trader activities with a weight of 0.57 . Another risk was the risk of low quality with a weight of 0.43 . This risk was caused by the low rice price because of low quality, such as inadequate rice. Prices sold by retailers range from IDR9,500 to IDR12,000 per kg. In addition, the quality of rice was sometimes low and diverse, and thus, consumers refuse or become more selective when purchasing rice. Groats in rice is another important factor (Beloshapka et al., 2016) that probably makes consumers refuse to buy rice.

\section{Risks at the Consumer Level}

The risk identification at the consumer level by using the fuzzy AHP revealed that the highest priority risk faced by consumers in the semi-organic rice supply chain was the price risk. Other encountered risks were the supply and quality risks. The assessments will produce priority weights to examine the value of each risk. The rating was considered valid because its $\mathrm{CR}$ value was 0.04 or $<0.1$. The following figures summarize the results of calculations using fuzzy. Three criteria were employed to explore the risks to actors of semi-organic rice supply chains. They were the supply, price, and quality. The following structures are the weighting of priority risk criteria and risk sub-criteria at the consumer level. 


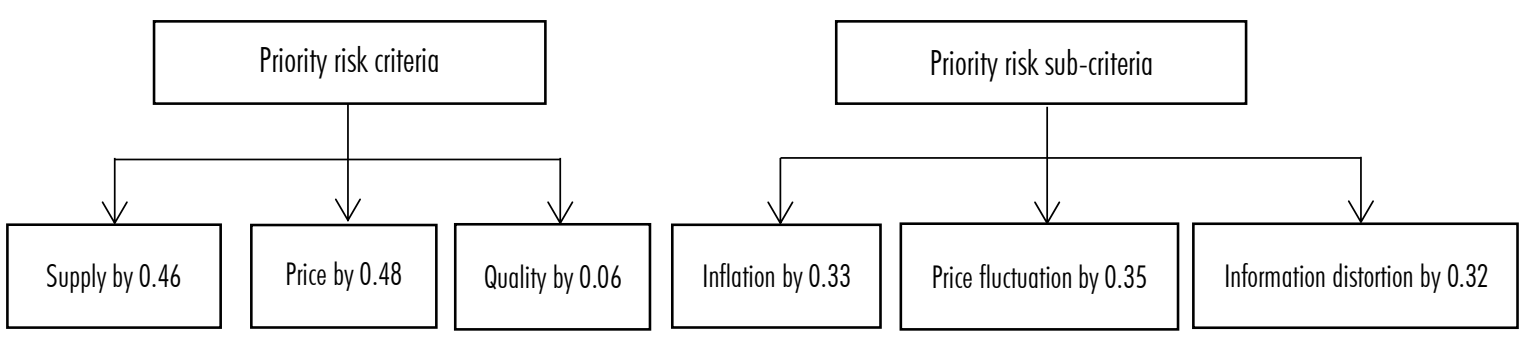

FIGURE 13. PRIORITY WEIGHTING STRUCTURE OF RISK CRITERIA AT THE CONSUMER LEVEL
FIGURE 14. PRIORITY WEIGHTING STRUCTURE OF PRICE RISK SUB-CRITERIA AT THE CONSUMER LEVEL

Figure 13 shows that the highest risk priority at the consumer level was price risk by 0.48. The supply risk weights 0.46 , and the quality risk weights 0.06 . The data of risks at the consumer level processed by the fuzzy AHP are provided by three respondents. Table 14 shows that the highest risk priority experienced by consumers was the price risk by 0.48 . Therefore, the price risk had the biggest or most important influence among the other five risks to consumers of semi-organic rice. Meanwhile, the weight of the supply risk was 0.46 , and the weight of the quality risk was 0.06 . The price risk had several risk sub-criteria, such as inflation, price fluctuations, and information distortion. The questionnaire using the fuzzy AHP revealed that the highest risk priority of the price fluctuation was at the consumer level. Consumers frequently encounter price fluctuations because of the low quality, falling rice prices, and rising rice prices due to rising demand (Costantino et al., 2012).

\section{Risk Mitigation Strategies for Actors of Each Semi-Organic Rice Supply Chains}

This research employed risk mitigation strategies to improve the occurring risks in semiorganic rice (Talluri, Kull, Yildiz, \& Yoon, 2013). The strategies applied for semi-organic rice supply chains in Watugede Village are expected to minimize the risk. Mitigation strategies are conducted by discussion between researchers and respondents, who are actors (Di Falco \& Bulte, 2013) in the semi-organic rice supply chains. The risk mitigation of risk priorities encountered by actors in each supply chain is explained as follows.

\section{Risk Mitigation Strategies at the Supplier Level}

Table 1 describes those suppliers perceive three risks that occur at the supplier level. The first was the supply risk, namely the uncertain supply risk. The second was the quality risk, namely the low-quality risk. The third was the environmental risk, namely government policy risk. The fuzzy AHP analysis discovered that the highest risk priority was the supply risk, namely the uncertain supply risk. To deal with the uncertain supply problem, sharing information in the supply chain, optimizing the level of supply readiness, and measuring supply chain performance are highly needed (Zhou \& Benton, 2007).

Risk Mitigation Strategies at the Farmer Level

Table 1 describes those farmers perceive five risks occurring at the farm level. The first was the supply risk, consisting of the uncertain supply risk. The second was the price risk, 
consisting of the inflation and price fluctuation risk. The third was the quality risk, consisting of the risk of low quality. The fourth was the environmental risks, consisting of the government policy, pest or disease, and competitors' product risks. The fifth was production risk, consisting of the risk of an unachieved production target. The fuzzy AHP analysis revealed that the highest risk priority was the environmental risk, consisting of the pest or disease risk. This risk is preventable by cleaning land or environmental sanitation, cleaning grass or bushes where rats nest, installing nursery curtains when rice is sown, dismantling rat holes, and killing the physical states of the rats directly (Di Falco \& Bulte, 2013).

TABLE 1. PERCEPTION AND EVALUATION RESULTS OF THE HIGHEST RISK PRIORITIES FOR ACTORS OF SEMI-ORGANIC RICE SUPPLY CHAINS

\begin{tabular}{|c|c|c|c|c|c|c|c|}
\hline Criteria & Sub-criteria & Supplier & Former & Logger & Grinder & Trader & Consumer \\
\hline \multirow[t]{2}{*}{ Supply } & Diverse supplies & & & & $\checkmark$ & & \\
\hline & Uncertain supplies & $\boldsymbol{V}$ & $\checkmark$ & $\checkmark$ & $\checkmark$ & $\checkmark$ & $\checkmark$ \\
\hline \multirow[t]{3}{*}{ Transportation } & Infrastructure damages & & & & & & \\
\hline & Uncertain transportation time & & & & $\checkmark$ & & \\
\hline & $\begin{array}{l}\text { Insecure road } \\
\text { Long haul distances }\end{array}$ & & & & & & \\
\hline \multirow[t]{3}{*}{ Prices } & Inflation & & $\checkmark \checkmark$ & & & & \\
\hline & Price fluctuations & & $\checkmark$ & $\checkmark$ & $\vee$ & $\checkmark$ & $\checkmark$ \\
\hline & Information distortion & & & $\checkmark$ & $\checkmark$ & $\checkmark$ & \\
\hline \multirow[t]{2}{*}{ Quality } & Low quality & $\checkmark$ & $\checkmark$ & $\checkmark$ & $\checkmark$ & $\checkmark \checkmark$ & $\checkmark$ \\
\hline & Quality variation & & & $\checkmark$ & $\checkmark$ & $\checkmark$ & $\checkmark$ \\
\hline \multirow[t]{6}{*}{ Environment } & Natural disasters & & & & & & \\
\hline & Government policies & $\checkmark$ & $\checkmark$ & $\checkmark$ & & & \\
\hline & Climates & & $\checkmark$ & $\checkmark$ & $\checkmark$ & & \\
\hline & Political, social, and cultural conditions & & & & & & \\
\hline & Pests/diseases & & $\checkmark$ & & & $\checkmark$ & \\
\hline & Competitive products & & $\checkmark$ & $\checkmark$ & $\checkmark$ & $\checkmark$ & \\
\hline \multirow[t]{4}{*}{ Production } & Production capacities & & & & & & \\
\hline & Inefficient production processes & & & & & & \\
\hline & Not achieved targets & & $\checkmark$ & & & & \\
\hline & Use of technology & & & & & & \\
\hline
\end{tabular}

Risk Mitigation Strategies at The Logger Level

Table 1 shows that the loggers perceive four risks occurring at the logger level. The first was the supply risk, comprising of the uncertain supply risk. The second was the price risks, comprising price fluctuations and information distortion risks. The third was the quality risks, comprising low quality and various quality risks. The fourth was the environmental risk, comprising government policy, climate, and competitors' product risks (Zhou \& Benton, 2007). The AHP fuzzy analysis found that the highest risk priority for the environmental risk was the risk of competitors' products. If the harvest in other cities is big, the products freely enter the village. This condition makes the price fall, and the logger suffers from losses (Di Falco \& Bulte, 2013). There are several efforts to minimize the risks: 
1. Communicating more with farmers,

2. paying more attention to rice planting schedules to minimize falling prices and maintain the supply availability when there is a big harvest outside Watugede Village,

3. relating the government policies to several products entering Watugede Village, and

4. hoarding unhusked rice in advance to keep the stock and increase rice production.

\section{Risk Mitigation Strategies at the Grinder Level}

Table 1 represents that the grinders perceive five risks occurring at the grinder level. The first was the supply risks, such as the diverse supply and uncertain supply risks. The second was the transportation risk, such as uncertain transportation time. The third was the price risks, such as price volatility and information distortion risks. The fourth was the quality risk, such as the low quality and various quality risks. The fifth was the environmental risk, such as the climate risk. The sixth was the production risk, such as the competing product risk (Di Falco \& Bulte, 2013). The AHP fuzzy analysis revealed that the highest risk priority was the price risk, consisting of the price fluctuation risk. (Zhou \& Benton, 2007) propose several efforts to minimize the risks:

1. More maintaining quality of rice produced,

2. obtaining raw materials of grain, and

3. always updating the information of prevailing grain and rice prices in the market.

\section{Risk Mitigation Strategies at the Trader Level}

Table 1 presents that the retail traders perceive four risks occurring at the retail trader level. The first was the supply risk, consisting of the uncertain supply risk. The second was the price risks, consisting of the risks of price fluctuations and information distortion. The third was the quality risks, consisting of the risk of low quality and the risk of various quality. The fourth was the environmental risks, consisting of the pest or disease risk and the competing product risk. The AHP fuzzy analysis found that the highest risk priority was the price risk, consisting of the price fluctuation risk, and the quality risk, consisting of the risk of various quality. An effort to minimize the risks is building cooperation among traders to control rice prices in the market (Di Falco \& Bulte, 2013). In addition, frequently fluctuating prices require intervention from the government to stabilize rice prices (Zhou \& Benton, 2007)

\section{Risk Mitigation Strategies at the Consumers Level}

Table 1 shows that the consumer perceived three risks occurring at the consumer level. The first was the supply risk, comprising of uncertain supply risk. The second was the price risk, comprising of the price fluctuation risk. The third was the quality risk, comprising lowquality and various quality risks. The AHP fuzzy analysis discovered that the highest risk priority was the price risk, comprising of the price fluctuations. The risk can be minimized by maintaining stable prices in all parties or actors of the supply chain from the downstream to the upstream (Zhou \& Benton, 2007). 


\section{CONCLUSION}

This study concludes several principal findings. This conclusion is related to the introduction and aims or hypothesis but does not repeat the discussion. Moreover, the conclusion was written briefly, critically, logically, and honestly following the discovered facts. Moreover, the discussion was written cautiously if there had been a generalization.

Actors involved in semi-organic rice supply chains in Watugede Village, Singosari District were suppliers, farmers, loggers, grinders, traders, and consumers. The risks at the supplier level were supply, quality, and environment risks. Risks at the farm level awere the supply, price, quality, environment, and production risks. Risks at the logging level were supply, price, quality, and environment risks. Risks at the grinder level were supply, transportation, price, quality, environment, and production risks. Risks at trader levels were supply, price, quality, and environment risks. Finally, risks at the consumer level were supply, price, and quality risks.

The evaluation of the highest risk priority in supply chain actors employed the fuzzy AHP and revealed several points. The risks at the supplier level were the supply risk and the supply risk sub-criteria, such as the uncertain supply risk. The risks at the farm level were the environmental risk and environmental risk sub-criteria, such as the pest or disease risk. The risks at the logistical level were environmental risks and environmental risk sub-criteria, such as the risk of competing products. The risks at the grinder level were the price risk and the price risk sub-criteria, such as the price fluctuation risk. The risks at the retail level were price risk and quality risk. The price risk subcategory constitutes the price fluctuation risk. Meanwhile, the quality risk subcategory constitutes the risk of various quality. The risks at the consumer level were the price risk and price risk sub-criteria, such as the price fluctuation risk.

The risks at the supplier level can be prevented by sharing information along the supply chains, optimizing the level of supply availability, measuring supply chain performance, and building more coordination with government subsidies. The risks at the farm level can be prevented by clearing land or environmental sanitation, cleaning grass or bushes where rats nest, installing nursery curtains when rice is sown, dismantling rat holes, and killing rats' physical states directly. The risks at falling prices can be minimized by improving government policies on products entering Watugede Village and hoarding unhusked rice. Consequently, stocks remain. Another effort is increasing rice production. The risks at the grinder level can be minimized by maintaining the quality of rice production, obtaining raw materials of grains, and always following the information of prevailing grain and rice prices in the market. The risks at the retail trader level can be minimized by building cooperation among traders to control rice prices in the market. Moreover, frequently fluctuating prices require intervention from the government to stabilize rice prices. The risks at the consumer level can be minimized by maintaining stable price stability in all parties or actors in the supply chain from the downstream to the upstream.

Acknowledgments: We would like to express our sincere gratitude to the Directorate of Research and Community Service, General Directorate for Strengthening Research and 
Development of the Ministry of Research, Technology, and Higher Education (RISTEKDIKTI) for funding this research through the community service in the community partnership program no. 579 in 2019.

\section{REFERENCE}

Beloshapka, A. N., Buff, P. R., Fahey, G. C., \& Swanson, K. S. (2016). Compositional analysis of whole grains, processed grains, grain co-products, and other carbohydrate sources with applicability to pet animal nutrition. Foods, 5(2), 1-16. https://doi.org/10.3390/foods5020023

Blome, C., \& Schoenherr, T. (2011). Supply chain risk management in financial crises - A multiple case-study approach. International Journal of Production Economics, 134(1), 4357. https://doi.org/10.1016/j.ijpe.2011.01.002

Bollapragada, R., Rao, U. S., \& Zhang, J. (2004). Managing inventory and supply performance in assembly systems with random supply capacity and demand. Management Science, 50(12), 1729-1743. https://doi.org/10.1287/mnsc.1040.0314

Cachon, G. P., \& Lariviere, M. A. (1999). Capacity choice and allocation: strategic behavior and supply chain performance. Management Science, 45(8), 1091-1108. https://doi.org/10.1287/mnsc.45.8.1091

Costantino, N., Dotoli, M., Falagario, M., Fanti, M. P., \& Mangini, A. M. (2012). A model for supply management of agile manufacturing supply chains. International Journal of Production Economics, 135(1), 451-457. https://doi.org/10.1016/j.ijpe.2011.08.021

Di Falco, S., \& Bulte, E. (2013). The Impact of Kinship Networks on the Adoption of RiskMitigating Strategies in Ethiopia. World Development, 43, 100-110. https://doi.org/10.1016/j.worlddev.2012.10.011

Ellram, L. M. (1990). The Supplier Selection Decision in Strategic Partnerships. Journal of Purchasing and Materials Management, 26(4), 8-14. https://doi.org/10.1111/j.1745493x.1990.tb00515.x

Feng, Q. (2010). Integrating dynamic pricing and replenishment decisions under supply capacity uncertainty. Management Science, 56(12), 2154-2172. https://doi.org/10.1287/mnsc. 1100.1238

Food and Agriculture Organization. (2021). Gross domestic product and agriculture value added 1970-2019. Global and regional trends. In FAOSTAT analytical briefs. Rome, Italy: Food and Agriculture Organization. Retrieved from https://www.fao.org/documents/card/en/c/cb4651en/

Halldórsson, Á., Kotzab, H., \& Skjøtt-Larsen, T. (2009). Supply chain management on the crossroad to sustainability: a blessing or a curse? Logistics Research, 1, 83-94. https://doi.org/10.1007/s12159-009-0012-y

Hammoudi, A., Hoffmann, R., \& Surry, Y. (2009). Food safety standards and agri-food supply chains: An introductory overview. European Review of Agricultural Economics, 36(4), 469478. https://doi.org/10.1093/erae/jbp044 
Kahraman, C., Cebeci, U., \& Ulukan, Z. (2003). Multi-criteria supplier selection using fuzzy AHP. Logistics Information Management, 16(6), 382-394. https://doi.org/10.1108/09576050310503367

Matzembacher, D. E., \& Meira, F. B. (2019). Sustainability as business strategy in community supported agriculture: Social, environmental and economic benefits for producers and consumers. British Food Journal, 121(2), 616-632. https://doi.org/10.1108/BFJ-032018-0207

Novak, S., \& Eppinger, S. D. (2001). Sourcing by design: Product complexity and the supply chain. Management Science, 47(1), 189-204. https://doi.org/10.1287/mnsc.47.1.189.10662

Queirós, A., Faria, D., \& Almeida, F. (2017). Strengths and Limitations of Qualitative and Quantitative Research Methods. European Journal of Education Studies, 3(9), 369-387. https://doi.org/10.5281/zenodo.887089

Santis, R. B. de, Golliat, L., \& Aguiar, E. P. de. (2017). Multi-criteria supplier selection using fuzzy analytic hierarchy process: case study from a Brazilian railway operator. Brazilian Journal of Operations Eु Production Management, 14(3), 428. https://doi.org/10.14488/bjopm.2017.v14.n3.a15

Spekman, R. E., \& Davis, E. W. (2004). Risky business: Expanding the discussion on risk and the extended enterprise. International Journal of Physical Distribution and Logistics Management, 34(5), 414-433. https://doi.org/10.1108/09600030410545454

Talluri, S. (Sri), Kull, T. J., Yildiz, H., \& Yoon, J. (2013). Assessing the Efficiency of Risk Mitigation Strategies in Supply Chains. Journal of Business Logistics, 34(4), 253-269.

Tang, O., \& Nurmaya Musa, S. (2011). Identifying risk issues and research advancements in supply chain risk management. International Journal of Production Economics, 133(1), 2534. https://doi.org/10.1016/j.ijpe.2010.06.013

Wu, W. Y., Chang, M. L., \& Chen, C. W. (2008). Promoting innovation through the accumulation of intellectual capital, social capital, and entrepreneurial orientation. REED Management, 38(3), 265-277. https://doi.org/10.1111/1467-9914.00120-i1

Zhou, H., \& Benton, W. C. (2007). Supply chain practice and information sharing. Journal of Operations Management, 25(6), 1348-1365. https://doi.org/10.1016/j.jom.2007.01.009 